\title{
A prospective study of the pattern of morbidity and medication use during antenatal and perinatal period in mothers of neonates admitted to neonatal intensive care unit of a tertiary care hospital
}

\author{
P. Anitha ${ }^{1 *}$, H. T. Yashoda ${ }^{2}$
}

\author{
${ }^{1}$ Department of Pharmacology, \\ Sri Siddhartha Medical College, \\ Tumkur, Karnataka, India \\ ${ }^{2}$ Department of Paediatrics, \\ Kempegowda Institute of \\ Medical Sciences, Bangalore, \\ Karnataka, India \\ Received: 10 September 2018 \\ Accepted: 05 October 2018 \\ *Correspondence to: \\ Dr. P. Anitha, \\ Email: anitaprabhu16@ \\ gmail.com
}

Copyright: (C) the author(s), publisher and licensee Medip Academy. This is an openaccess article distributed under the terms of the Creative Commons Attribution NonCommercial License, which permits unrestricted noncommercial use, distribution, and reproduction in any medium, provided the original work is properly cited.

\begin{abstract}
Background: Most drugs taken by pregnant women can cross the placenta (except high molecular weight drugs like heparin) and expose the foetus to pharmacologic and teratogenic effects. The drugs used in the late antenatal and intranatal period may have a potential perinatal and neonatal outcome.

Methods: The pattern of maternal morbidity and drug use was assessed prospectively in 150 consecutive mothers of neonates admitted to NICU. The number of drugs used, therapeutic class, dose, route, frequency and purpose of use were recorded. The efficacy and safety of medications was assessed by neonatal outcome.

Results: The most common maternal morbidity during pregnancy was PIH, eclampsia, hypothyroidism, GDM, PROM, oligohydromnias, anemiaorpolyhydromnias, and $4 \%(n=6)$ had more than one complication. Different therapeutic classes of drugs were used as per the prevailing clinical conditions or complications. The total number of drugs used was 26 , with an average of 3.68 per subject. AMAs were the most commonly used drugs, chosen empirically and used in combination for prophylaxis or control of infections. Other classes of drugs were used for specific indications. None of the NICU admissions in the present study seem to be related to antenatal or perinatal drug exposure. The treatment outcome was very good in most of the subjects and no drug related adverse events or interactions were observed.

Conclusions: Maternal morbidity and drugs administered to mother play an important role in improving the neonatal outcome.
\end{abstract}

Keywords: Maternal morbidity, Maternal medication use, Neonatal outcome

\section{INTRODUCTION}

Most drugs taken by pregnant women can cross the placenta (except high molecular weight drugs like heparin) and expose the foetus to pharmacologic and teratogenic effects. ${ }^{1}$ The harmful effects depend upon the nature of the drug, its dose and route of administration, the stage of pregnancy at which the drug is used and the genetic constitution and susceptibility of the fetus. ${ }^{2}$ The drugs used in the late antenatal and intranatal period may have a potential perinatal and neonatal outcome. The drugs commonly used during this stage include analgesics, anaesthetics, antibiotics, oxytococics and tocolytics and various prophylactic medications. ${ }^{3}$

The use of NSAIDs during late pregnancy is associated with adverse effects such as oligohydramnios, fetal renal dysfunction, and premature closure of ductusarteriosus leading to pulmonary hypertension in the newborn. Salicylates given at term can cause neonatal hemorrhage, 
methemoglobinemia and platelet dysfunction. General anesthetics and the drugs used for analgesia during labour like opioids can cause neonatal respiratory depression and difficulty in initiating breathing at birth. Accidental injection of local anaesthetics into the foetal scalp during paracervical block can result in apnea, hypotonia, bradycardia, intractable convulsions in the neonates soon after birth. Prilocaine can cause methemoglobinemia, and spinal bupivacaine has been associated with increased risk of jaundice in newborn. ${ }^{4}$ Oxytocin administration for induction of labour is associated with higher incidence of neonatal jaundice probably because of hyposmolality of the plasma due to its vasopressin like action resulting in hemolysis. ${ }^{5}$ Antihypertensive drugs such as propranolol can cause foetal bradycardia and neonatal hypoglycemia when administered during late pregnancy. Hydralazine use can result in neonatal thrombocytopenia; captopril use can result in foetal and neonatal renal failure. Tocolytic agents like $\beta 2$ agonistssuch as terbutaline, ritodrine and isoxsuprine can cause neonatal hypoglycemia and IVH. Magnesium sulfate can cause neonatal side effects like lethargy, hypotonia, respiratory depression and IVH. ${ }^{6,7}$

Most of the drugs administered to the mother are secreted into breast milk in small amounts. The concentration of drugs achieved in breast milk is usually low (i.e. less than therapeutic dose). Most antibiotics taken by mother can be detected in breast milk e.g. tetracycline (concentration in breast milk approximately $70 \%$ of maternal serum concentration which leads to tooth staining in infants). The concentration of isoniazid in breast milk is high enough to cause pyridoxine deficiency in neonate if the mother is not given pyridoxine supplements.

Most of the sedatives and hypnotics achieve higher concentration in breast milk. Barbiturates and benzodiazepenes can produce lethargy, sedation and poor suckling reflex in neonate. Opioids such as heroin, methadone and morphine can prolong the state of neonatal narcotic dependence if the drug was taken chronically by the mother during pregnancy. Breast feeding is contraindicated after large doses of iodinated 125I albumin because it leads to thyroid suppression and increased risk of thyroid carcinoma (10 fold) in the neonate. Breast feeding should be avoided in mothers receiving cancer chemotherapy, cytotoxic or immunomodulating agents. ${ }^{1,8}$

Foetal therapeutics is administration of drugs during pregnancy with foetus as the target, to achieve certain specific therapeutic effects on the fetus and also to prevent various postnatal complications. e.g. glucocorticoids for foetal lung maturation in anticipated preterm labour, dexamethasone for treatment of congenital adrenal hyperplasia, phenobarbitone to induce foetal hepatic enzymes responsible for glucuronidation of bilirubin, and to reduce incidence of jaundice in newborn, antiarrhythmic drugs like digoxin, flecainide, procainamide, verapamil for treatment of foetal cardiac arrhythmias., ${ }^{1,9}$ Antenatal prophylaxis with vitamin $\mathrm{K} 1$ is indicated in anticipated preterm labour and also in women receiving antiepileptic drugs (phenobarbitone, primidone, carbamazepine etc) during pregnancy. Other examples of foetal drug therapy include treatment of polyhydramnios with indomethacin and glucocorticoids for immune thrombocytopenia. ${ }^{9}$ Maternal use of zidovudine and a single dose of nevirapine during labour can reduce HIV transimission to the neonate. ${ }^{10}$

The objective of the present endeavour was to study the pattern of maternal morbidity, to study the pattern of maternal drug use and to assess the efficacy and safety of medications by neonatal outcome.

\section{METHODS}

Prospective analysis of case records of 150 mothers of neonates admitted to NICU and receiving one or more medications, was included in the present study. Approval and clearance from the Institutional Ethics Committee was obtained before starting the study. Written informed consent was obtained from parents/ legal representatives of all the study subjects after fully explaining the study procedure to their satisfaction, in both English and vernacular language. This study was carried out from January 2013 to June 2014. Mothers of neonates admitted to NICU and willing to give written informed consent were included in the study

The obstetric history, type of delivery, the pattern of medication uses in the antenatal and perinatal period, and discharge status were recorded. The details of medication i.e., number of drugs used, the therapeutic class / category of drugs, the dose, route, frequency and duration of administration. The efficacy and safety/tolerability of the medications was assessed by monitoring the neonatal outcome. In addition, any medications received by breast feeding mothers were also recorded. All the relevant data were entered and documented in case record forms (CRF). Relevant findings in laboratory investigations were noted down.

\section{Statistical analysis}

The data collected was analysed by using descriptive statistics, namely mean and standard deviation for quantitative variables. The results were also depicted in the form of tables and graphs. Microsoft word and excel were used for the analysis of data and to generate graphs and tables.

\section{RESULTS}

The demographic data is presented in Table 1 . The mean age of the mothers was $24.50 \pm 4.04$ years, and majority of the mothers $(84 \%)$ were in the age group between $20-29$ years. Though the increasing maternal age is likely to be associated with more neonatal complications requiring NICU admission, only 7 mothers in the present study were aged $>35$ years, suggesting various other factors being 
more important than just maternal age. $66.66 \%$ of the mothers $(n=100)$ were primiparous.

Table 1: Demographic data.

\begin{tabular}{|c|c|c|}
\hline \multicolumn{2}{|l|}{ Variable } & Number (\%) \\
\hline \multicolumn{2}{|c|}{ Maternal age $($ Mean \pm SD) } & $24.50 \pm 4.04$ \\
\hline \multicolumn{2}{|c|}{$\begin{array}{l}\text { Gestational age } \\
(\text { weeks })(\text { Mean } \pm S D)\end{array}$} & $35.21 \pm 2.00$ \\
\hline \multirow{2}{*}{$\begin{array}{l}\text { Gender of } \\
\text { neonate }(\%)\end{array}$} & Male & $93(62)$ \\
\hline & Female & $57(38)$ \\
\hline \multirow{2}{*}{$\begin{array}{l}\text { Place of birth } \\
(\%)\end{array}$} & Inborn* & $77(51.4)$ \\
\hline & Outborn $^{\dagger}$ & $73(48.6)$ \\
\hline \multicolumn{2}{|c|}{ Birth weight $(\mathrm{kg})($ Mean \pm SD $)$} & $2.20 \pm 0.77$ \\
\hline \multirow{3}{*}{ Births } & Singleton & $132(88.00)$ \\
\hline & Twins & $15(10.00)$ \\
\hline & Triplets & $3(2.00)$ \\
\hline \multirow{2}{*}{$\begin{array}{l}\text { Apgar score } \\
(\text { Mean } \pm \text { SD) }\end{array}$} & At $1 \mathrm{~min}$ & $6.33 \pm 2.53$ \\
\hline & At $5 \mathrm{~min}$ & $7.45 \pm 2.67$ \\
\hline \multirow{3}{*}{$\begin{array}{l}\text { Mode of } \\
\text { delivery }\end{array}$} & Normal delivery & $85(56.60)$ \\
\hline & LSCS & $61(40.60)$ \\
\hline & Instrumental delivery* & $4(2.80)$ \\
\hline
\end{tabular}

*Inpatients; ${ }^{\dagger}$ Transferred from other centres

Table 2 presents the obstetric history for maternal morbidity and complications. Only $28.6 \%$ of the mothers had the history of morbidity during pregnancy like PIH, eclampsia, hypothyroidism, GDM, PROM, oligohydromnias, anemia or polyhydromnias, and $4 \%$ $(n=6)$ had more than one complication.

Table 2: Obstetrical history, maternal morbidity/ complications $(n=150)$.

\begin{tabular}{|ll|}
\hline Morbidity/complications & $\begin{array}{l}\text { No. of subjects } \\
\text { n }(\%)\end{array}$ \\
\hline PIH, Eclampsia & $13(8.60)$ \\
\hline Hypothyroidism & $4(2.66)$ \\
\hline GDM & $5(3.40)$ \\
\hline PROM & $12(8.00)$ \\
\hline Oligohydromnias & $4(2.60)$ \\
\hline Anemia & $4(2.00)$ \\
\hline Polyhydromnias & $1(0.60)$ \\
\hline More than one complication $^{\dagger}$ & $6(4.00)$ \\
\hline
\end{tabular}

GDM+Polyhydromnias $(\mathrm{n}=1), \mathrm{GDM}+\mathrm{PROM}(\mathrm{n}=1), \mathrm{GDM}+\mathrm{PIH}$ $(\mathrm{n}=1)$, PIH+anemia $(\mathrm{n}=1)$, PROM+Oligohydromnias $(\mathrm{n}=1)$, $\mathrm{PROM}+\mathrm{PIH}(\mathrm{n}=1)$

Table 3 summarizes the maternal exposure to various antenatal and perinatal medications. The data regarding medications was available only for 77 mothers, and all received more than one medication.

The antenatal medications for various maternal illnesses included methyldopa $(n=8)$, labetolol $(n=3)$ and nifedipine $(n=2)$ for PIH; insulin $(n=5)$ for GDM, thyroxine $(n=4)$ for hypothyroidism; magnesium sulphate $(n=1)$ for eclampsia; isoxsuprine $(n=5)$ for tocolysis; betamethasone $(n=8)$ for fetal lung maturation. The drugs used for PIH, GDM and hypothyroidism were continued during lactation.

Table 3: Antenatal and perinatal medications (maternal).

\begin{tabular}{|c|c|c|}
\hline $\begin{array}{l}\text { Drugs used* } \\
\text { (generic name) }\end{array}$ & $\begin{array}{l}\text { No. of } \\
\text { subjects } \\
(n=77)^{\dagger}\end{array}$ & Purpose \\
\hline Methyl dopa $\$$ & 8 & PIH \\
\hline $\begin{array}{l}\text { Magnesium } \\
\text { sulphate }\end{array}$ & 1 & Eclampsia \\
\hline Labetolol $^{\$}$ & 3 & PIH \\
\hline Nifedipine $^{\$}$ & 2 & $\mathrm{PIH}$ \\
\hline Insulin $\$$ & 5 & GDM \\
\hline $\begin{array}{l}\text { Thyroxine } \\
\text { sodium\$ }\end{array}$ & 4 & Hypothyroidism \\
\hline Isoxsuprine & 5 & Tocolytic \\
\hline Bupivacaine & 38 & Epidural analgesia \\
\hline Oxytocin & 29 & Induction of labour \\
\hline $\begin{array}{l}\text { Methyl } \\
\text { ergometrin }\end{array}$ & 21 & PPH \\
\hline Betamethasone & 8 & Fetal lung maturation \\
\hline $\begin{array}{l}\text { Nitrous } \\
\text { oxide+Oxygen }\end{array}$ & 4 & $\begin{array}{l}\text { Obstetrical analgesia/ } \\
\text { anesthesia }\end{array}$ \\
\hline Fentanyl & 8 & Obstetrical analgesia \\
\hline Propofol & 4 & Induction of anesthesia \\
\hline Glycopyrolate & 4 & $\begin{array}{l}\text { Premedication to } \downarrow \\
\text { airway secretion }\end{array}$ \\
\hline Succinylcholine & 4 & SMR for intubation \\
\hline Atracurium & 4 & SMR during LSCS \\
\hline Ondansetron & 28 & $\begin{array}{l}\text { Suppress post- } \\
\text { operative vomiting }\end{array}$ \\
\hline Ranitidine & 39 & $\begin{array}{l}\text { Antisecretory to } \\
\downarrow \text { gastric acidity }\end{array}$ \\
\hline Pantoprazole & 38 & $\begin{array}{l}\text { Antisecretory to } \\
\downarrow \text { gastric acidity }\end{array}$ \\
\hline Tramadol & 18 & $\begin{array}{l}\text { Post-operative } \\
\text { analgesia }\end{array}$ \\
\hline $\begin{array}{l}\text { Ibuprofen+ } \\
\text { Paracetamol }^{\#}\end{array}$ & 34 & $\begin{array}{l}\text { Post-operative } \\
\text { analgesia }\end{array}$ \\
\hline Diclofenac & 24 & $\begin{array}{l}\text { Post-operative } \\
\text { analgesia }\end{array}$ \\
\hline $\begin{array}{l}\text { Trypsin+Chymo } \\
\text { trypsin" }\end{array}$ & 56 & $\begin{array}{l}\text { To reduce wound } \\
\text { swelling }\end{array}$ \\
\hline
\end{tabular}

*All subjects received more than one medication. Postnatal prophylactic AMAs (ceftriaxone+sulbactam or cefixime IV) were used in all subjects. Vitamin and mineral supplements were used in most of the subjects. ${ }^{\dagger}$ Data unavailable $(n=73)$ due to transfer from another hospitals \#Fixed dose combination. ${ }^{\$}$ Medications continued in breast feeding mothers because of morbidity.

The perinatal medications included bupivacaine $(n=38)$ for epidural analgesia; oxytocin $(n=29)$ for induction of labour; methylergometrin $(n=21)$ for PPH;nitrous oxide+oxygen $(n=4)$, fentanyl $(n=8)$ for obstetrical analgesia; propofol $(n=4)$ for induction of anesthesia; glycopyrolate $(n=4)$ as premedication to reduce airway secretion; succinylcholine $(n=4)$ for intubation, atracurium 
$(n=4)$ as muscle relaxant during LSCS; ranitidine $(n=39)$, pantoprazole $(n=38)$ to reduce gastric acidity; tramodol $(n=18)$, ibuprofen + paracetamol $(n=34)$, diclofenac $(n=24)$ for postoperative analgesia; ondansetron $(n=28)$ to suppress postoperative vomiting and trypsin + chymotrypsin $(n=56)$ to reduce wound swelling.

Table 4 summarizes neonatal treatment outcome. $92.66 \%$ of the subjects $(n=139)$ showed good clinical improvement with stabilized condition and were shifted out of NICU. 3 subjects with CHD and other malformations were referred for surgical intervention. However, death occurred in 2 subjects, one preterm neonate died 4 days after admission due to pulmonary hemorrhage, and the other due to birth asphyxia and respiratory failure after 2 days. 9 subjects (6\%) were not available for further assessment as they were discharged against medical advice for various reasons.

Table 4: Treatment outcome $(n=150)$.

\begin{tabular}{|ll|}
\hline Outcome & No. of subjects n (\%) \\
\hline Improved $^{*}$ & $139(92.66)$ \\
\hline Not available for assessment $^{\dagger}$ & $9(6.00)$ \\
\hline Death $^{\#}$ & $2(1.33)$ \\
\hline
\end{tabular}

*Condition stabilized and shifted out of NICU; 3 subjects with $\mathrm{CHD}$ and other malformations referred for surgical intervention. ${ }^{\dagger}$ As the subjects were discharged against medical advice. ${ }^{\#}$ One preterm subject died 4 days after admission due to pulmonary hemorrhage, and the other due to birth asphyxia and respiratory failure after 2 days.

\section{DISCUSSION}

The number of NICU admissions increased with maternal age, probably because of increased preterm birth and other complications. ${ }^{11,12}$ Though parity may not significantly affect the relative risk of NICU admission, the risk of infection appeared to be more with multiple siblings. ${ }^{12,13}$ Though majority of the mothers of the study subjects $(n=101)$ did not have any history of morbidity during pregnancy, various maternal morbid factors during pregnancy are known to be associated with increased neonatal complications, the late preterm neonates exposed to APH and hypertensive disorders of pregnancy being more vulnerable (Table 2). ${ }^{14}$

Methyldopa has a very good safety record during pregnancy and lactation, and neonatal complications are extremely rare except occasional occurrence of hypotension. Labetolol has occasionally produced low birth weight in neonates due to decreased placental perfusion. Nifedipine has no reported adverse effects in the newborn. Though magnesium sulphate increased the perinatal mortality in low birth weight neonates when used as tocolytic in preterm labour, the dose used in eclampsia to control seizures appears to be safe. Isoxsuprine used as a tocolytic in preterm labour is known to produce fetal tachycardia. Bupivacaine used for epidural analgesia has occasionally produced neonatal jaundice. Oxytocin has been reported to produce hemolysis in newborn by inducing hyposmolality of plasma. No adverse neonatal outcome is reported for methylergometrin used for PPH. Betamethasone has been reported to produce low cortisol secretion in neonates because of HPA suppression. Though nitrous oxide and propofol have no reported neonatal adverse outcome, fentanyl is reported to cause fetalbradycardia and neonatal respiratory depression. No neonatal adverse events have been reported for glycopyrolate, succinylcholine and atracurium. The various postoperative medications employed are known to be safe during lactation. ${ }^{5,15-17}$

\section{CONCLUSION}

Though many drug related complications have been reported in neonates with various antenatal and perinatal medications, none of the NICU admissions in the present study seem to be related to antenatal or perinatal drug exposure. However maternal morbidity and drugs administered to mother play an important role in improving the neonatal outcome.

\section{ACKNOWLEDGEMENTS}

Authors would like to thank all the study participants.

Funding: No funding sources

Conflict of interest: None declared

Ethical approval: The study was approved by the Institutional Ethics Committee

\section{REFERENCES}

1. Koren G. Special aspects of perinatal and pediatric pharmacology. In: Katzung BG, Masters SB, Trevor AG, eds. Basic and Clinical Pharmacology. 12th ed. New Delhi: McGraw Hill; 2012:1039-1050.

2. Satoskar RS, Rege NN, Bhandarkar SD. Drugs, pregnancy and the infant. In: Pharmacology and Pharmacotherpeutics. 22nd ed. Mumbai: Saurabh Printers; 2011:1098-1108.

3. Uppal R, Chhabra A, Narang A. Pattern of drug use in neonatal intensive care unit. Indian Pediatr. 1998 Jul;35(7):647.

4. Singh M. Perinatal pharmacology. In: Care of the Newborn. 5th ed. Sagar publications; 1999:76-85.

5. Sweetman SC, editor. Martindale. In: The Complete Drug Reference. 37th ed. London: Pharmaceutical press; 2011:2178.

6. Dutta D C. Pharmacotherapeutics in obstetrics. In: Konar $\mathrm{H}$ editor. Text book of Obstetrics 6th ed. Calcutta: New Central Book Agency; 2004:498-519.

7. Sweetman SC, editor. In: Martindale. The Complete Drug Reference. 37th ed. London: Pharmaceutical press; 2011:1827.

8. Walson PD. Pediatric clinical pharmacology and therapeutics. In: Speight TM, Holford NHG, eds. Avery's drug treatment 4th ed, Adis press; 1997:127171. 
9. Theis JG, Koren G. Maternal and Fetal clinical pharmacology. In: Speight TM, G Holford NH, eds. Avery's drug treatment 4th ed, Adis press;1997:75126.

10. World Health Organization. Antiretroviral drugs for treating pregnant women and preventing HIV infection in infants: Programmatic update 2012. Available at: http://www.whoonline.org. Accessed on 1.07.2013.

11. de Jongh BE, Locke R, Paul DA, Hoffman M. The differential effects of maternal age, race/ethnicity and insurance on neonatal intensive care unit admission rates. BMC Pregnancy Childbirth. 2012 Dec;12(1):97.

12. Lisonkova S, Janssen PA, Sheps SB, Lee SK, Dahlgren L. The effect of maternal age on adverse birth outcomes: does parity matter?. J Obstetr Gynaecol Canada. 2010 Jun 1;32(6):541-8.

13. Yoon HS, Shin YJ, Ki M. Risk factors for neonatal infections in full-term babies in South Korea. Yonsei Med J. 2008 Aug 30;49(4):530-6.

14. Shapiro-Mendoza CK, Tomashek KM, Kotelchuck M, Barfield W, Nannini A, Weiss J, et al. Effect of latepreterm birth and maternal medical conditions on newborn morbidity risk. Pediatrics. 2008 Feb 1;121(2):e223-32.

15. Ostrea EM, Mantaring JB, Silvestre MA. Drugs that affect the fetus and newborn infant via the placenta or breast milk. Pediatr Clin. 2004 Jun 1;51(3):539-79.

16. Writer WD, Stienstra R, Eddleston JM, Gatt SP, Griffin R, Gutsche BB, et al. Neonatal outcome and mode of delivery after epidural analgesia for labour with ropivacaine and bupivacaine: a prospective metaanalysis. Br J Anaesthesia. 1998 Nov 1;81(5):713-7.

17. Sweetman SC, edr. Martindale. The Complete Drug Reference. 37th ed. London: Pharmaceutical Press; 2011:59.

Cite this article as: Anitha P, Yashoda HT. A prospective study of the pattern of morbidity and medication use during antenatal and perinatal period in mothers of neonates admitted to neonatal intensive care unit of a tertiary care hospital. Int J Basic Clin Pharmacol 2018;7:2223-7. 